\title{
ESTIMATION OF QUALITY ATTRIBUTES AND FRYING TIMES OF COTTONSEED AND SUNFLOWER OIL BLEND DURING DEEP-FAT FRYING OF POTATO CHIPS
}

\author{
Hassan, I . M. \& Abou-Arab, A .A. \\ Food Science Dept., Faculty of Agric. Ain-Shams Univ. Cairo, Egypt
}

\begin{abstract}
The chemical, physical and some sensory changes induced upon deep-fat frying of potato chips in a blend of cottonseed and sunflower oil were investigated. The chemical changes were correlated with the frying times aiming at establishing prediction models for estimating frying times. The oil blend became dark in colour after each successive frying. The correlation coefficient between the frying time and $\mathrm{A}_{400}$ was very high $(\mathrm{r}=0.9967)$. Similar trend was also observed in the relationship between the frying times and $\mathrm{A}_{450}$. Oil viscosity increased significantly with increasing frying times indicating evidence of thermal decomposition of frying oil blend. The correlation coefficient between the frying times and the refractive index was high $(\mathrm{r}=0.9898)$. Slight and continuous losses in unsaturated fatty acids of the oil blend during deep-fat frying of potato chips have taken place.

The peroxide value (meq $\mathrm{O}_{2} / \mathrm{kg}$ oil) increased initially from 3.86 to 11.81 after 10 fryings, then dropped to 5.23 after 20 fryings followed by another rapid increase to 19.76 (meq. $\mathrm{O}_{2} / \mathrm{kg}$ oil) after 30 fryings. The UV absorption at $232 \mathrm{~nm}$ increased initially from 0.4 to 1.5 after only 5 fryings and unchanged from the $5^{\text {th }}$ frying to the $20^{\text {th }}$ frying then dropped after 30 fryings. A considerable increase in the TBA value has occurred up to the $20^{\text {th }}$ frying and then the TBA value showed no change for the next 10 fryings. The correlation coefficient between the frying time and TBA value was 0.93 .

The rate of polar compounds formation for the first 5 fryings was $3.62 \mathrm{mg} / 100 \mathrm{mg}$ oil $/ \mathrm{hr}$. whereas from the $5^{\text {th }}$ frying to the $30^{\text {th }}$ frying such rate was reduced to only $1.12 \mathrm{mg} / 100 \mathrm{mg}$ oil $/ \mathrm{hr}$. Sensory evaluation of the oil blend indicated that odour and colour scores were inversely related to the frying time. The most important and accurate mathematical models which express the relationship between the independent and dependant variables were established. The frying time could be successfully and accurately predicted by wise and intelligent chose of dependant variables incorporated in the best fit equations.
\end{abstract}

Keywords : quality attributes, deep-fat frying, cottonseed oil, sunflower oil, potato chips

\section{INTRODUCTION}

Changes that may occur in nutritional value of oils heated to high temperatures in deep-fat frying process are in concern with deep-fat fried foods assuring a place of importance in the diets of many individuals (Bennion, 1967). A premise has been accepted that frying-oil chemistry is incredibly complex and has provided many opportunities for organic and analytical chemists. A measure of the heat abuse taking place in oil and an understanding of the products formed during deep-fat frying are of great interest and importance from the consumer point of view and to the food industry as well (White, 1991). The visible changes taking place in a fat or oil during frying include dark colour, an increase in viscosity, decrease in smoke point and an increase in foaming (Perkins, 1967, Rock \& Roth, 1967, Tangel et al., 1977, Gere, 1983). Intermittent heating and cooling of cottonseed oil showed that when oil heated for only $62 \mathrm{hr}$ for several intervals, it contains as much polar materials as oil heated continuously for $166 \mathrm{hr}$. This is apparently caused by an increase in fatty acyl peroxides as the oil cools and their decomposition upon heating, causing further damage to the fat. This is repeated with each heating and cooling cycles. The presence of water introduced as steam upon frying is greatly accelerated the deterioration of oil (Perkins \& Van Akkeren, 1965).

The chemical reactions of oxidation, polymerization, and hydrolysis occur rapidly during deep-fat frying. The extent of these reactions depends on frying conditions, princ-ipally the temperature, duration, and aeration involved. The kind of food being fried also affects the resulting composition of the frying fat. In frying oils, fatty acids are released and their concentration in the cooking fat increases with repeated use (Clark \& Serbia, 1991).

Measurement of heat abuse of oils should be based on the changes described. 
Many methods of analysis measure the formation of volatile or nonvolatile components or some portions or indicators of change in the fraction. The measurement of volatile decomposition products is very time-consuming and tedious. On the other hand, the nonvolatile decomposition products (NVDPs) remain in the frying fat to promote further degradation and are absorbed by the fried food and thus subsequently eaten by the consumer (Stevenson et al., 1984).

Determination of total polar compounds (PCs) has proven to be accurate, simple, reproducible and one of approved standard methods of IUPAC (1987). A level of 25$27 \%$ PCs has been suggested as the limit beyond which a restaurant should discard its frying oil (Paradis \& Nawar, 1981a, b).

When polyunsaturated fatty acids (PUFAs) are oxidized, a shift in one of the double bonds occurs, producing conjugated dienes that can be measured by ultraviolet absorption at $232 \mathrm{~nm}$. The absorbance increases initially, and then become stable during frying. This has been related to the establishment of equilibrium between the rates of formation of polymers formed by a Diels-Alder reaction involving conjugated dienes (Peled et al., 1975). A large decrease in PUFAs of oils used for frying were reported by Fleischman et al. (1963) in comparing with fatty acid composition of the same brand of oil before use.

The methods available for measuring heat abuse in frying oils ranged from simple to complex and vary in their accuracy (White, 1991). Therefore, the present study aims at continuing efforts of researchers to provide more information and shade the light on frying stability and frying performance of cotton seed and sunflower oil blend $(1: 1 \mathrm{w} / \mathrm{w})$ which is used extensively in Egypt. This current research emphasized on the chemical changes occur in this oil blend when used in deep-fat frying of some popular fried products namely potato chips to simulate their processing in Egypt's restaurants. Establishing prediction models for estimating the frying times and/or number of frying from the known dependant variables is also considered.

\section{MATERIALS AND METHODS}

\section{Materials :}

A vegetable oil blend of cottonseed and sunflower oil $(1: 1 \mathrm{w} / \mathrm{w})$ was obtained from a local processing oil company. The potatoes purchased from the local market having the following composition, moisture $77.48 \pm 0.87 \%$, protein $2.18 \pm 0.23 \%$, fat $0.41 \pm 0.09 \%$, ash $1.13 \pm$ $0.06 \%$ and total carbohydrates $18.80 \pm 1.12 \%$. Potatoes was peeled and sliced into elliptical chips (6cm diameter, $1.20 \mathrm{~mm}$ thickness) and sub-merged in water until needed. Four thermo-statically controlled Phillips deep-fat fryers with aluminum interior and frying basket were used for the deep-fat frying of potato chips. Exactly $3 \mathrm{~L}$ oil blend were heated from $26^{\circ} \mathrm{C}$ to $180^{\circ} \mathrm{C}$ within $8.5 \mathrm{~min}$. and a batch of potato chips weighing $500 \mathrm{~g}$ was fried for 8.5$9.0 \mathrm{~min}$. until the potato chips colour reach to the desired light brown golden colour. The oil blend was subjected to 30 consecutive fryings within 4 days. The batches were fried half-hour intervals for $2.5 \mathrm{hr}$ (5 fryings) on the first and $2^{\text {nd }}$ days and then 5 hr/day (10 fryings) for two consecutive days. The oil temperature was found to be ranged between 116 to $180^{\circ} \mathrm{C}$ during frying operations. The oil was not replenished with fresh oil during frying operation, but after each 10 fryings, one fryer was poured to the other fryers to reach the original volume. On the $3^{\text {rd }}$ and $4^{\text {th }}$ day, the oil was allowed to cool after each 5 fryings to $30^{\circ} \mathrm{C}$ within $3.5 \mathrm{hr}$ and then the oil was heated again to $180^{\circ} \mathrm{C}$ to start a new frying cycle. Table (1) shows the time-temperature relationship during each 5 consecutive fryings. After frying operations, the weight of potato chips was reduced to $24.77 \pm 1.35 \%$ (average of 50 replicates) from the original weight. Frying experiment at the final stage was conducted in two replicates as the contents of two fryers were emptied to the others.

\section{Analytical methods:}

Oil samples were withdrawn after $0,5,10$, 15,20 and 30 fryings in duplicate for analysis.

The colour of the oil $(20 \%$ in chloroform) was measured at 400 and $450 \mathrm{~nm}$ using a Unicam HE $\lambda$-IOS $\alpha$ UV-visible Specrophotometer (model v 2.03) (Hassan, 1980).

Oil viscosity was determined in centipoises at $25^{\circ} \mathrm{C}$ prior the initial frying and after 5,10 , 15,20 and 30 fryings as described by Jaslyn, (1950).

The refractive index of each sample was taken concurrent with both colour and viscosity determination using Abbé refractometer with a circulating water bath at $25^{\circ} \mathrm{C} \pm 0.1^{\circ} \mathrm{C}$ according to AOAC (1995).

Fatty acid composition: The oil blend (cottonseed and sunflower oil) of unused and 
used frying oil was analyzed in duplicate for fatty acid composition by the gas chromatographic procedure. After preparation of methyl esters, analysis was performed in a Perkin-Elmer Gas Liquid Chromatograph series 8300 with flame ionization detector equipped with a $2 \mathrm{~m}$ column (packed with $15 \%$ Ov-275, chromosorb W, A/W, 80/100). The chromatographic conditions were as follows: Injection port temperature, $240^{\circ} \mathrm{C}$, and column temperature was $100^{\circ} \mathrm{C}$ for $2 \mathrm{~min}$. and increased to $190^{\circ} \mathrm{C}$ with rate of $7^{\circ} \mathrm{C} / \mathrm{min}$, then isothermally for $20 \mathrm{~min}$ at $190^{\circ} \mathrm{C}$, the detector temperature was $240^{\circ} \mathrm{C}$ (Ashour, 1991). Identification of the fatty acids on the chromatogram was made by comparing the retention times of the frying oil methyl esters with those of known mixtures of methyl esters run on the same column under the same conditions. The fatty acid composition was expressed as area perce-ntage of the total area from all methyl esters.

Free fatty acids (FFA's), peroxide value (PV) and polar compounds \% (PC's) were determined in triplicate according to AOAC (1995).
Natural conjugated and unconjugated constituents were determined using UV absorption at 232 and $268 \mathrm{~nm}$ in purified solvent using (using a Unicam HE $\lambda$-IOS $\alpha$ UV-visible Specrophotometer model v 2.03) as described by Danopolus \& Ninni (1972). Thiobarbituric acid value (TBA) was determined as $\mathrm{mg}$ malonaldehyde/kg oil as described by Keeney (1971).

Sensory analysis: The odour intensity of the frying oil was evaluated by trained, experienced 15 member panel after $0,2.5,5$, $7.5,10$, and $15 \mathrm{hr}$ of heating, frying and cooling cycles. Panelists rated the oil odour for overall intensity on a 10-point intensity scale with $10=$ excellent oil odour and $0=$ strong unacceptable odour. Colour of the frying oil was also evaluated using the same previously mentioned scale with $10=$ excellent colour and $0=$ dark unacceptable colour (Kramer \& Twigg, 1970).

Statistical analysis and mathematical models: The standard error was computed (Larmond, 1970). A correlation test was applied to study the relationship between different components and the frying times and/or

Table 1: Changes in frying temperatures of cottonseed and sunflower oil blend (1:1) during the first five frying of potato chips

\begin{tabular}{|c|c|c|c|c|c|c|c|c|c|c|}
\hline \multirow{3}{*}{$\begin{array}{l}\text { Time } \\
\text { (min) }\end{array}$} & \multicolumn{10}{|c|}{ Temperature $\left({ }^{\circ} \mathrm{C}\right)$} \\
\hline & \multicolumn{2}{|c|}{ Frying No (1) } & \multicolumn{2}{|c|}{ Frying No (2) } & \multicolumn{2}{|c|}{ Frying No (3) } & \multicolumn{2}{|c|}{ Frying No (4) } & \multicolumn{2}{|c|}{ Frying No (5) } \\
\hline & Pan (1) & Pan (2) & Pan (1) & Pan (2) & Pan (1) & Pan (2) & Pan (1) & Pan (2) & Pan (1) & Pan (2) \\
\hline$\overline{0}$ & 26 & 26 & 147 & 150 & 130 & 134 & 96 & 97 & 140 & 140 \\
\hline 1 & 45 & 39 & 158 & 164 & 148 & 149 & 104 & 104 & 148 & 149 \\
\hline 2 & 51 & 51 & 172 & 177 & 156 & 157 & 120 & 122 & 165 & 166 \\
\hline 3 & 82 & 80 & $180^{*}$ & $180 *$ & 176 & 179 & 144 & 142 & $180^{*}$ & $180 *$ \\
\hline 4 & 94 & 94 & 126 & 119 & $180^{*}$ & $180 *$ & 162 & 162 & 126 & 124 \\
\hline 5 & 115 & 115 & 122 & 117 & 122 & 116 & $180^{*}$ & $180 *$ & 120 & 125 \\
\hline 6 & 130 & 127 & 122 & 120 & 129 & 120 & 125 & 125 & 122 & 124 \\
\hline 7 & 155 & 157 & 131 & 124 & 132 & 126 & 124 & 117 & 126 & 128 \\
\hline 8 & $180 *$ & $180^{*}$ & 134 & 135 & 138 & 133 & 126 & 120 & 138 & 137 \\
\hline 9 & 130 & 121 & 145 & 144 & 147 & 144 & 132 & 127 & 144 & 148 \\
\hline 10 & 122 & 114 & 156 & 152 & 155 & 154 & 138 & 136 & 160 & 164 \\
\hline 11 & 124 & 118 & 168 & 166 & 170 & 170 & 145 & 149 & 174 & $180 * *$ \\
\hline 12 & 129 & 124 & $180 * *$ & $179 * *$ & $180 * *$ & $180 * *$ & 160 & 160 & $180 * *$ & 182 \\
\hline 13 & 138 & 133 & 187 & 185 & 190 & 192 & 172 & 178 & 190 & 194 \\
\hline 14 & 140 & 140 & 190 & 191 & 185 & 187 & $180 * *$ & $180 * *$ & 187 & 189 \\
\hline 15 & 154 & 152 & 184 & 183 & 180 & 178 & 188 & 190 & 184 & 184 \\
\hline 16 & 166 & 166 & 182 & 185 & 176 & 174 & 185 & 186 & 180 & 181 \\
\hline 17 & $180 * *$ & $176 * *$ & 175 & 179 & 170 & 170 & 180 & 180 & 170 & 170 \\
\hline 18 & 185 & 186 & 170 & 174 & 166 & 166 & 170 & 169 & 163 & 165 \\
\hline 20 & 188 & 190 & 160 & 163 & 164 & 164 & 161 & 160 & 166 & 166 \\
\hline 21 & 180 & 184 & 152 & 154 & 154 & 158 & 155 & 158 & 160 & 161 \\
\hline 23 & 170 & 174 & 150 & 151 & 145 & 148 & 148 & 148 & 158 & 156 \\
\hline 25 & 166 & 169 & 142 & 144 & 140 & 142 & 145 & 143 & 150 & 152 \\
\hline 27 & 158 & 162 & 136 & 141 & 136 & 138 & 140 & 140 & 145 & 145 \\
\hline 29 & 154 & 153 & 133 & 136 & 130 & 133 & 134 & 132 & 138 & 136 \\
\hline 30 & 147 & 150 & 130 & 133 & 129 & 130 & 130 & 130 & 133 & 130 \\
\hline
\end{tabular}


the number of fryings. Simple and multiple regression analysis were carried out using Excel Program "Windows 2000".

\section{RESULTS AND DISCUSSION}

Data in Table (2) reveal that, the oil blend (cottonseed and sunflower oil) became dark after each successive frying. The colour of the oil blend, deteriorated continuously with the elongation of frying times. The correlation coefficient between the frying times $(\mathrm{X})$ and $\mathrm{A}_{400}(\mathrm{Y})$ was very high $(\mathrm{r}=0.9967)$. The corresponding value of $\mathrm{R}^{2}(0.9933)$ indicates that about $99 \%$ of changes in $\mathrm{A}_{400}$ were attributed to the extension of frying time. The linear regression equation for prediction the frying time of the oil blend was:

\section{$Y\left(A_{400}\right)=0.244+0.0292 X($ time $/$ hr $)$}

Where: $\mathrm{Y}$ is the $\mathrm{A}_{400}$ and $\mathrm{X}$ is predicted frying time from the same Table.

When the similar time-temperature relationship was observed between the frying times and $\mathrm{A}_{450}$, slight lower correlation coefficient was undertaken as seen in Table (2). However, a positive proportional relationship was found between the frying times $(\mathrm{X})$ and $\mathrm{A}_{450}(\mathrm{Y})$ where the $r$ and $R^{2}$ values were 0.896 and 0.803 , respectively and the obtained equation was:

\section{$\mathrm{A}_{450}=0.124+0.00694 \mathrm{X}$ (time/hr)}

Table (2) also shows the viscosity of the oil blend over the course of 30 fryings. The mean viscosity for the unused oil blend (6 replicates) was $50.64 \pm 0.52$ centipoise $\mathrm{X}$ $\mathrm{g} / \mathrm{cm}^{3}$ at $25^{\circ} \mathrm{C}$. Oil viscosity increased significantly with extension the frying times as well as frying numbers. Carlin et al. (1954) and Defouw et al. (1981) reported that increment of viscosity was evidence of the thermal decomposition of frying fat. High correlation coefficient was observed between the frying time and viscosity $(\mathrm{r}=$ 0.9269). A level of 70 centipoise of oil blend from cottonseed and sunflower oil could be suggested as the limit (15-20 fryings) beyond which this oil should be discarded as will be discussed.

Refractive index (RI) of the oil blend during repeating of the discontinuous deepfat fryings of potato chips is gradually increased as shown in Table (1). This increment may be attributed to polymer formation and thermal degradation of the oil (Carlin et al., 1954, Tyagi \& Vasishtha, 1996) during the deep-fat frying process. The correlation coefficient between the frying time and RI was very high $(r=0.9898)$.

The effects of frying numbers in fatty acid compositon of cottonseed and sunflower oil blend used in deep fat frying of potato chips are shown in Table (3). Although the calcul-ations were carried out by the integrator of the gas chromatogram on the basis of the fractional peak areas, there was an apparent slight increase in saturated fatty acids and a relative decrease in polyenoic acids content of oil blend as frying numbers increased. The percentages of unsaturated fatty acids in the oil blend particularly those for monoenes and dienes were high $(76.89 \%)$. Lauric $\left(\mathrm{C}_{12: 0}\right)$, myristic $\left(\mathrm{C}_{14: 0}\right)$, palmetoleic $\left(\mathrm{C}_{16: 1}\right)$, linolenic $\left(\mathrm{C}_{18: 3}\right)$ and arachidonic $\left(\mathrm{C}_{20: 0}\right)$ acids were presented in the oil blend in trace amounts. The slight loss in unsaturated fatty acids $\left(\mathrm{C}_{18: 1}\right.$ and $\mathrm{C}_{18: 2}$ ) during deep-fat frying of potato chips in the oil blend may be attributed to oxidative polymerization, scission, cyclization and other side reactions that would have taken place

Table 2: Effect of number and time of deep frying on absorptivity (400 and 450nm), viscosity and RI of cottonseed and sunflower oil blend used in processing of potato chips.

\begin{tabular}{lccccc}
\hline No of frying & $\begin{array}{c}\text { Frying } \\
\text { Time hr } \mathbf{( X )}\end{array}$ & $\mathbf{A}_{\mathbf{4 0 0}}(\mathbf{Y}) \pm \mathbf{S E}$ & $\mathbf{A}_{\mathbf{4 5 0}}(\mathbf{Y}) \pm \mathbf{S E}$ & $\begin{array}{c}\text { Viscosity (CP) } \\
(\mathbf{Y}) \pm \text { SE }\end{array}$ & $\begin{array}{c}\text { Refractive index } \\
(\mathbf{R I})\end{array}$ \\
\hline 0 & 0.0 & $0.225 \pm 0.000$ & $0.100 \pm 0.010$ & $50.64 \pm 0.52$ & 1.4692 \\
5 & 2.5 & $0.323 \pm 0.032$ & $0.145 \pm 0.007$ & $56.60 \pm 1.43$ & 1.4695 \\
10 & 5.0 & $0.405 \pm 0.050$ & $0.170 \pm 0.010$ & $64.52 \pm 0.84$ & 1.4696 \\
15 & 7.5 & $0.467 \pm 0.040$ & $0.190 \pm 0.014$ & $68.20 \pm 0.95$ & 1.4700 \\
20 & 10.0 & $0.543 \pm 0.040$ & $0.210 \pm 0.014$ & $70.54 \pm 0.61$ & 1.4701 \\
30 & 15.0 & $0.670 \pm 0.000$ & $0.205 \pm 0.000$ & $72.19 \pm 0.43$ & 1.4705 \\
\hline & & $\mathrm{Y}=0.244+0.0292 \mathrm{X}$ & $\mathrm{Y}=0.124+0.00694 \mathrm{X}$ & $\mathrm{Y}=54.1+1.46 \mathrm{X}$ & $\mathrm{Y}=1.47+8.6 \times 10^{-5} \mathrm{X}$ \\
\hline Calculated T (time/hr) & 24.49 & 4.04 & 4.94 & 13.87 \\
F & & 599.64 & 16.34 & 24.38 & 192.41 \\
r & & 0.9967 & 0.8963 & 0.9269 & 0.9898 \\
$\mathrm{R}^{2}$ & & 0.9933 & 0.8034 & 0.8591 & 0.9796 \\
\hline
\end{tabular}


Table 3: Fatty acid composition (\%) of cottonseed and sunflower oil blend as affected by deep-fat frying of potato chips.

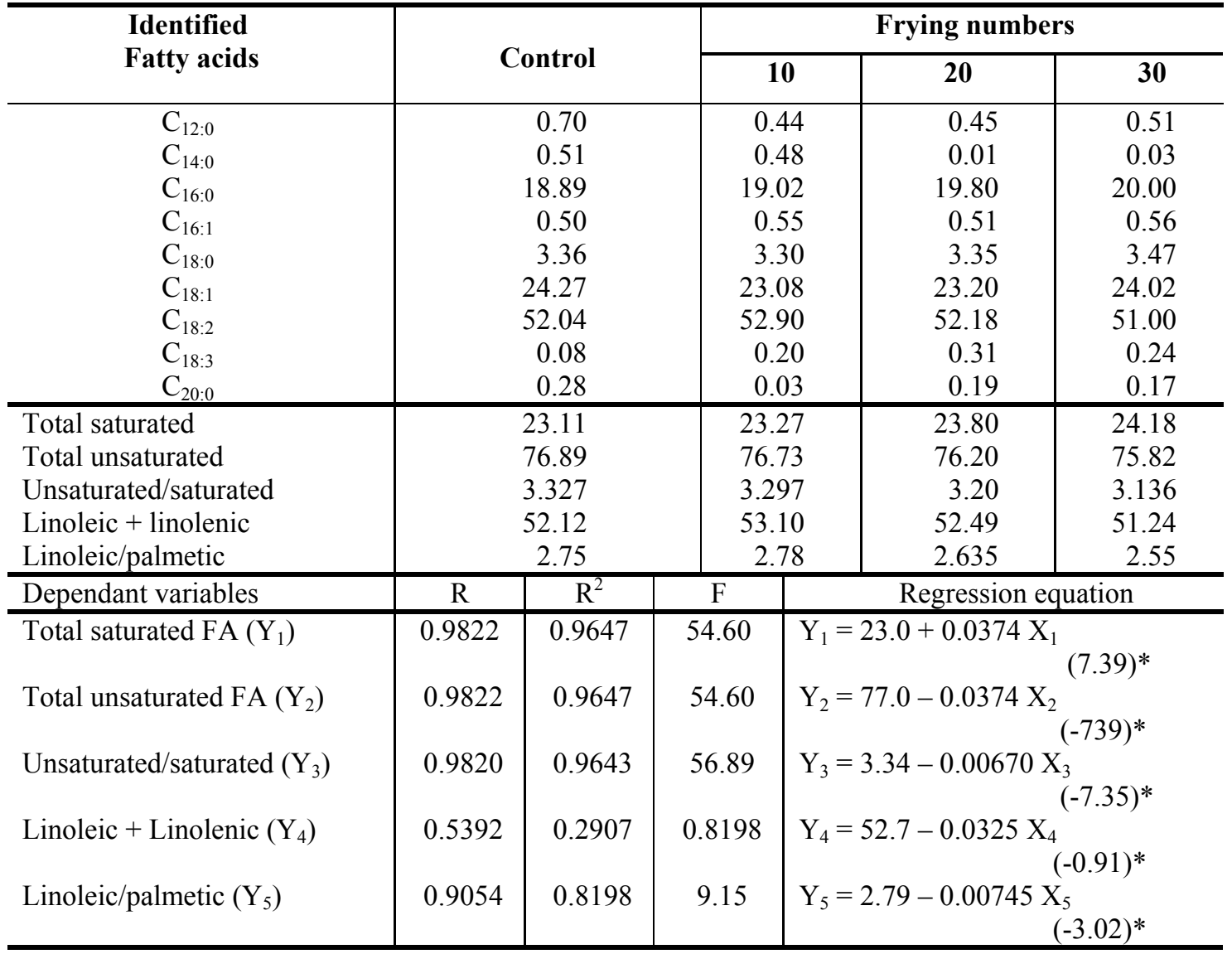

* Values under the equations indicate the calculated " $\mathrm{t}$ ".

during the course of deep-fat frying (Tyagi \& Vasishtha, 1996).

The effect of number and time of deep-fat frying on some chemical properties of cotton seed and sunflower oil blend used in deep-fat frying of potato chips is shown in Table (4). Acid value of fresh oil was $0.155 \mathrm{mg} \mathrm{KOH} / \mathrm{g}$ oil and reached to 0.434 after $15 \mathrm{hr}$ of repeating the discontinuous frying. The steady rise in acid value can be attributed partly to both the hydrolysis of tri-glyceride (TG) of oil and to the carboxylic groups present in the formed polar polymeric products during frying (Perkins, 1967, Peled et al., 1975).

The peroxide value of fresh oil blend increased from 3.86 to 11.81 (meq. $/ \mathrm{kg}$ oil) after ten fryings then dropped to 5.23 after 20 fryings followed by another rapid increase to 19.76 (meq./kg oil) after 30 fryings. Increment of peroxide means that the rate of peroxides formation was more than their degradation, and vice versa when decreased. The correlation coefficient between the frying time and peroxide value was relatively low $(r=0.6449)$ es- pecially when compared with that of other determined chemical parameters.

Table (4) illustrates the UV absorption of the oil blend during deep-fat frying of potato chips. The UV absorption at $232 \mathrm{~nm}$ changed initially from 0.4 to 1.5 after only 5 fryings and unchanged from the $5^{\text {th }}$ frying to the $20^{\text {th }}$ frying then dropped after 30 fryings. As seen from Table (4), the correlation coefficient between the frying times and $\mathrm{A}_{232}$ was too weak $(r=0.0494)$. On the other hand, the UV absorption at $268 \mathrm{~nm}$ was 0.28 for fresh oil blend then reached 1.40 after 20 fryings and dropped suddenly to 0.3 after 30 fryings. This may be attributed to the volatilization of aldehydic and ketonic compounds which have been formed during the early stages of deepfat frying of potato chips in the oil blend.

Changes in TBA value as oxidation proceeds during deep-fat frying of potato chips are shown in Table (5). During repeating the discontinuous frying of potato chips in the oil blend, a considerable increase in the TBA values has occurred up to the $20^{\text {th }}$ frying and then 
Table 4: Acid value, peroxide value and UV absorption of cottonseed and sunflower oil blend as affected by deep-fat frying of potato chips

\begin{tabular}{|c|c|c|c|c|c|}
\hline \multirow{2}{*}{$\begin{array}{l}\text { No of } \\
\text { frying }\end{array}$} & \multirow{2}{*}{$\begin{array}{c}\text { Frying time } \\
\text { hr }(\mathrm{X})\end{array}$} & \multirow{2}{*}{$\begin{array}{l}\text { Acid value (Y) } \\
\text { (mg KOH/g oil) }\end{array}$} & \multirow{2}{*}{$\begin{array}{c}\text { Peroxide value } \\
\text { (Y) (mequ/Kg oil) }\end{array}$} & \multicolumn{2}{|c|}{ UV absorption } \\
\hline & & & & at $232(Y)$ & at $268(Y)$ \\
\hline 0 & 0 & $0.155 \pm 0.006$ & $3.86 \pm 0.24$ & $0.40 \pm 0.08$ & $0.28 \pm 0.01$ \\
\hline 5 & 2.5 & $0.228 \pm 0.011$ & $9.58 \pm 0.05$ & $1.50 \pm 0.15$ & $0.68 \pm 0.02$ \\
\hline 10 & 5.0 & $0.277 \pm 0.002$ & $11.81 \pm 0.37$ & $1.50 \pm 0.00$ & $0.87 \pm 0.00$ \\
\hline 15 & 7.5 & $0.271 \pm 0.002$ & $6.21 \pm 0.10$ & $1.50 \pm 0.00$ & $0.89 \pm 0.00$ \\
\hline 20 & 10.0 & $0.280 \pm 0.005$ & $5.23 \pm 0.01$ & $1.50 \pm 0.00$ & $1.40 \pm 0.03$ \\
\hline \multirow[t]{2}{*}{30} & 15.0 & $0.434 \pm 0.060$ & $19.76 \pm 0.18$ & $0.70 \pm 0.01$ & $0.30 \pm 0.01$ \\
\hline & & $Y=0.168+0.0160 X$ & $Y=4.75+0.699 X$ & $\mathrm{Y}=1.15+0.0046 \mathrm{X}$ & $Y=0.656+0.0121 X$ \\
\hline \multicolumn{2}{|c|}{ Calculated T (time/hr) } & 5.64 & 1.69 & 0.10 & 0.31 \\
\hline \multicolumn{2}{|l|}{$\mathrm{F}$} & 31.86 & 2.85 & 0.01 & 0.10 \\
\hline \multicolumn{2}{|l|}{$\mathrm{r}$} & 0.9426 & 0.6449 & 0.0494 & 0.1549 \\
\hline \multicolumn{2}{|l|}{$\mathrm{R}^{2}$} & 0.8884 & 0.4158 & 0.0024 & 0.0240 \\
\hline
\end{tabular}

the TBA value maintained stable for the next 10 fryings (up to 30 fryings). The correlation coefficient between the frying time and TBA value was high $(\mathrm{r}=0.9260)$. The prediction equation in Table (5) revealed that the frying time needed about $35 \mathrm{hr}$ for the formation of $1 \mathrm{mg}$ malonaldehyde in the oil blend when the same heating, conditions of oil are employed. Data in Table (5) show a dramatic increase of total PC's content from $10.0 \%$ in the unused oil to $19.05 \%$ when the oil was used for five fryings only. According to Blumenthal (1991), fat or oil must be discarded when its polar fraction is more than $25 \%$.

Results in Table (5) reveal that the levels of PC's $\%$ between the $15^{\text {th }}$ to $20^{\text {th }}$ frying ranged between $24.80 \%$ to $26.00 \%$ which are almost similar or slightly beyond the recommended levels (27\%) of oil discarding. From the prediction equation presented in the same Table, it could be anticipated that the formation of $1 \%$ PC's needs about $45 \mathrm{~min}$ of frying. The correlation coefficient between the frying times and
PC's\% was relatively high $(r=0.9527)$ indicating that PC's determination is one of the most promising and accurate methods of evaluating the quality of frying oils.

Odour and colour scores in Table (5) were inversely related to the frying times. Correlation coefficients between odour and colour scores and frying times were -0.9029 and 0.6381 , respectively. There were high standard deviations for sensory estimating of both oil odour and colour. However, the mean panel scores for oil colour were significantly higher than those for odour evaluations throughout the course of frying. It is found from the prediction equations give in Table (5), that the frying times could be accurately estimated by using odour scores $\left(\mathrm{X}_{1}\right)$ as a dependant variable, whereas colour scores did show less accuracy. The frying time $(\mathrm{X})$ of the used oil blend could be predicted more accurately when both dependant variables $\left(\mathrm{Y}_{1}\right.$ and $\left.\mathrm{Y}_{2}\right)$ are introduced in a multiple regression equation. From this equation, the calculated frying

Table 5: Thiobarbituric acid, polor compounds, odour and colour scores of cottonseed and sunflower oil blend as affected by deep-fat frying of potato chips

\begin{tabular}{llllll}
\hline $\begin{array}{c}\text { No of } \\
\text { frying }\end{array}$ & $\begin{array}{c}\text { Frying time } \\
\text { hr } \mathbf{( X )}\end{array}$ & $\begin{array}{c}\text { TBA (Y) } \\
\text { (mg alonaldehyde/Kg oil) }\end{array}$ & $\begin{array}{c}\text { Polar compounde } \\
(\mathbf{Y})(\mathbf{\%})\end{array}$ & Odour score (Y) & Colour score (Y) \\
\hline 0 & 0 & $0.533 \pm 0.004$ & $10.00 \pm 0.41$ & $8.17 \pm 1.47$ & $8.67 \pm 1.51$ \\
5 & 2.5 & $0.549 \pm 0.001$ & $19.05 \pm 0.90$ & $6.83 \pm 1.17$ & $7.33 \pm 1.86$ \\
10 & 5.0 & $0.574 \pm 0.020$ & $23.00 \pm 1.34$ & $6.83 \pm 1.47$ & $7.33 \pm 1.51$ \\
15 & 7.5 & $0.730 \pm 0.070$ & $24.80 \pm 0.21$ & $7.00 \pm 1.10$ & $7.67 \pm 1.75$ \\
20 & 10.0 & $0.820 \pm 0.009$ & $26.00 \pm 0.60$ & $6.17 \pm 1.17$ & $6.00 \pm 0.89$ \\
30 & 15.0 & $0.820 \pm 0.002$ & $33.00 \pm 1.44$ & $5.67 \pm 1.21$ & $7.17 \pm 1.17$ \\
& & $Y=0.517+0.0232 X$ & $Y=13.592+1.36 X$ & $Y=7.72-0.142 X$ & $Y=8.02-0.0989 X$ \\
Calculated T (time/hr) & 4.91 & 6.27 & -4.2 & -1.66 \\
F & & 24.07 & 39.29 & 17.65 & 2.75 \\
r & & 0.9260 & 0.9527 & -0.9029 & -0.6381 \\
$R^{2}$ & & 0.8575 & 0.9076 & 0.8152 & 0.4072 \\
\hline
\end{tabular}


time is estimated to be $15.07 \mathrm{hr}$ (30 fryings) when the oil blend should be rejected organolepticaly.

Multiple regression equations were established to evaluate the amount of heat which the oil blend has been exposed during repeating the discontinuous frying of potato chips. Table (6) presents the most important mathematical models which express the relation-ship between the independent variable $(\mathrm{X})$ and dependant variables $\left(\mathrm{Y}_{1}, \mathrm{Y}_{2}, \ldots, \mathrm{Y}_{8}\right)$. The multiple regression equation number " 1 " in Table (6) shows the relationship between the frying time (independent variables) and three dependant variables $\left(\mathrm{Y}_{1}=\mathrm{A}_{400}, \mathrm{Y}_{2}=\mathrm{A}_{450}\right.$ and $\mathrm{Y}_{3}=$ TBA value).The correlation coefficient between the frying time and these three variables was 0.9999 . In Table (6) the predicted frying times are compared with the corresponding real values. From these comparisons, it is appeared that the predicted values are almost similar to the real ones. On the other hand, the dependant variables introduced in equation 2 (Table 6) are $\mathrm{A}_{400}\left(\mathrm{Y}_{1}\right)$, acid value $\left(\mathrm{Y}_{5}\right)$ and peroxide value $\left(\mathrm{Y}_{7}\right)$. The correlation coefficient between these variables and the frying time $(\mathrm{X})$ was 0.9998 . The partial correlations between the frying times and the aforementioned variables were far below the correla- tion coefficient between the independent and the dependant variables included in the equations presented in Table (6).

In conclusion, the frying time or in other words the amount of heat received in $1: 1 \mathrm{w} / \mathrm{w}$ cottonseed and sunflower oil blend during repeating the discontinuous frying of potato chips could be successfully and accurately predicted by wise and intelligent chose of dependant variables incorporated in the suitable equations.

\section{ACKNOWLEDGEMENT}

The authors appreciate greatly the financial support from the Academy of Scientific Research and Technology (Egypt) for the research project "Rationalizing utiliz-ation of edible oils in local consumption". Also, they would like to express their respect to the assistance given by Prof. Dr. M.A. AbdAllah Prof. of Food Science Dept. Fac. of Agric., Ain Shams University for statistical analysis of the manuscript.

\section{REFERENCES}

AOAC. 1995. Official Methods of Analysis of AOAC International. 16 ${ }^{\text {th }}$ Ed., Vol. II. Edited by Cunniff, P., Virginia, USA.

Table 6: The best mathematical models employed for accurate evaluation of frying times of potato chips in cottonseed and sunflower oil blend (1:1) during repeating the discontinuous frying operations

\begin{tabular}{|c|c|c|c|c|c|c|}
\hline No & Best mathematical models & (r) & $\left(\mathbf{R}^{2}\right)$ & (F) & $\begin{array}{c}\text { True }(\mathrm{X}) \\
(\mathrm{hr})\end{array}$ & $\begin{array}{c}\text { Calculated (X) } \\
(\mathbf{h r})\end{array}$ \\
\hline 1 & $\begin{array}{c}\mathrm{X}=-7.79+37.7 \mathrm{Y} 1-27.6 \mathrm{Y} 2+3.90 \mathrm{Y} 3 \\
(49.07) \quad(-11.29) \quad(5.31)\end{array}$ & 0.9999 & 0.9999 & 6911.23 & 10.00 & 10.00 \\
\hline 2 & $\begin{array}{ccc}\mathrm{X}=-8.97+26.9 \mathrm{Y} 1+17.7 \mathrm{Y} 5- & 0.105 \mathrm{Y} 7 \\
(1.05) & (0.27) & (-0.23)\end{array}$ & 0.9998 & 0.9995 & 106.16 & 10.00 & 10.02 \\
\hline 3 & $\begin{array}{c}\mathrm{X}=-\mathrm{-} .75+43.5 \mathrm{Y} 1-0.230 \mathrm{Y} 4+0.0547 \mathrm{Y} 7 \\
(11.89) \quad(-2.84) \quad(1.64)\end{array}$ & 0.9994 & 0.9989 & 519.65 & 7.50 & 7.46 \\
\hline 4 & $\begin{array}{cc}\mathrm{X}=-16.1+20.8 \mathrm{Y} 3+31.4 \mathrm{Y} 5+0.022 \mathrm{Y} 7 \\
(4.06) \quad(2.25)\end{array}$ & 0.9994 & 0.9987 & 636.16 & 10.00 & 10.03 \\
\hline 5 & $\begin{array}{c}\mathrm{X}=-18.1+13.0 \mathrm{Y} 2+28.7 \mathrm{Y} 3+0.347 \mathrm{Y} 7 \\
(1.47) \quad(11.00)\end{array}$ & 0.9991 & 0.9982 & 374.11 & 10.00 & 9.98 \\
\hline 6 & $\begin{array}{c}\mathrm{X}=-17.4+28.6 \mathrm{Y} 3+0.0891 \mathrm{Y} 4+0.306 \mathrm{Y} 7 \\
(9.27) \quad(1.24)\end{array}$ & 0.9990 & 0.9979 & 318.56 & 5.00 & 5.03 \\
\hline 7 & $\begin{aligned} & \mathrm{X}=-14.4+17.4 \mathrm{Y} 3+ 0.415 \mathrm{Y} 4 \\
&(2.26) \quad(3.09)\end{aligned}$ & 0.9828 & 0.9659 & 42.46 & 5.00 & 5.08 \\
\hline 8 & $\begin{array}{c}X=-7.91+42.2 Y 1-0.175 Y 4 \\
(9.44) \quad(-1.90)\end{array}$ & 0.9985 & 0.9970 & 496.73 & 2.50 & 2.50 \\
\hline$Y_{5}=$ & $\begin{array}{ll}\text { me of frying }(\mathrm{hr}) . & \\
0 & \mathrm{Y}_{2}=\mathrm{A}_{450} \\
\text { id value } & \mathrm{Y}_{7}=\mathrm{Pv}\end{array}$ & & $\begin{array}{l}=\mathrm{TBA} \\
=\text { Refrac }\end{array}$ & ive index & $\begin{array}{l}\mathrm{Y}_{4}=\mathrm{P} \\
\mathrm{Y}_{9}=\mathrm{V}\end{array}$ & $\begin{array}{l}(\%) \\
\text { cosity }\end{array}$ \\
\hline
\end{tabular}


Ashour, A. A. 1991. Effect of Drought on Some Biochemical Constituents of Plant. Ph.D. Thesis, Fac. Agric. Ain Shams Univ. Cairo, p. 42.

Bennion, M. 1967. Effect of batter ingredients on changes in fatty acid composition of fats used for frying. Food Technol. 41: 1638.

Blumenthal, M.M. 1991. A new look at the chemistry and physics of deep-fat frying: Understanding the changes that frying oil goes through can lead to optimization of the frying process and better fried foods. Food Technol. 45: 68.

Carlin, G.T., Hopper, R.P.\& Rockwood, B.N. 1954. Some factors affecting the decomposition of frying fats. Food Technol. 8: 161.

Clark, W.L. \& Serbia, G.W. 1991. Safety aspects of frying oils. Food Technol. 45: 84.

Danopolus, A.A. \& Ninni, V.L. 1972. Detection of frozen fish deterioration by ultraviolet spectrophotometric method. J. Food Sci., 37: 649 .

DeFouw, C.L., Zabik, M.E. \& Gray, J.I. 1981. Fractionated edible beef tallow as a deepfat frying medium for French fries. J. Food Sci., 46: 452.

Fleischman, A.I., Florin, A., Fitzgerald, J., Caldwell, A.B. \& Eastwood, G. 1963. Studies on cooking fats and oils. J. Am. Assn. 42: 394.

Gere, A. 1983. Study of some factors affecting frying fat deterioration. Fette Seifen Anstrich. 85: 18.

Hassan, I. M. 1980. The Effect Of Irradiation Treatments Alone or Accompanied With Other Treatments on Some Properties of Meat. Ph.D. Thesis, Fac. Of Agric. Ain Shams Univ., Cairo, Egypt.

IUPAC. 1987. Determination of polar compounds in frying fats, Method 2.507. In "Standard Methods for Analysis of Oils, Fats and Derivatives, $7^{\text {th }}$ ed. IUPAC App. Chem. Commission on oils, Fats and Derivatives, ed. C. Paquot and A. Aautfenne, Blackwell Scientific Publications, Oxford, England.

Jaslyn, M.O.A. 1950. Method in food analysis. Academic Press. Inc., Publishers, New York.
Keeney, P.G. 1971. A guide to controlling oxidation in butter creams. Candy and Snack Ind., 136: 58.

Kamer, A. \& Twigg, B.A. (1970). Quality Control for the Food Industry, $3^{\text {rd }}$ ed., AVI Publishing Co., Westport.

Larmond, E. 1970. Methods for sensory evaluation of food. Publication No. 1284, Canada, Dept. of Agric., Ottawa.

Paradis, A.J. \& Nawar, W.W. 1981a. Evaluation of new methods for the assessment of used frying oils. J. Food Sci., 46: 449.

Paradis, A. J. \& Nawar, W.W. 1981b. A gas chromatography method for the assessment of used frying oils: Comparison with other methods. J. Am. Oil Chem. Soc. 58: 635.

Peled, M., Gutfinger, T. \& Letan, A. 1975. Effect of water and BHT on stability of cottonseed oil during frying. J. Sci. Food Agric. 26: 1655.

Perkins, E.G. 1967. Formation of non-volatile decomposition products in heated fats and oils. Food Technol. 21: 125.

Perkins, E.G. \& Van Akkeren, L.A. 1965. Heated fats. IV. Chemical changes in fats subjected to deep-fat frying processes: Cottonseed oil. J. Am. Oil Chem. Soc. 42: 782.

Rock, S.P. \& Roth, H. 1967. Factors affecting the rate of deterioration in the frying quality of fats. II. Type of heater and method of heating. J. Am. Oil Chem. Soc. 41: 531.

Stevenson, S.G., Vaisey-Genser, M. \& Eskin, N.A.M. 1984. Quality control in the use of deep-fat frying oils. J. Am. Oil Chem. Soc. 61: 1102 .

Tangel, F.P., Leeder, J.G. \& Chang, S.S. 1977. Deep-fat frying characteristics of butteroil. J. Am. Oil Chem. Soc. 42: 1110.

Tyagi, V.K. \& Vasishtha, A.K. 1996. Changes in the characteristics and composition of oil during deep-fat frying. J. AOCS., 73: 499.

White, P.J. 1991. Methods for measuring changes in deep-fat frying oils. Food Technol., 45: 75. 


\section{تقلير خصائص الجودة وعلد مرات القلى لخليط من زيت بذرة القطن

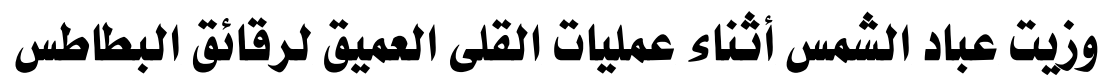

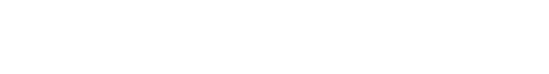

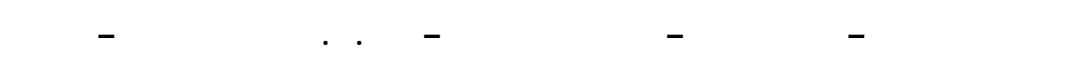

مم ققدير النغيرات الكيميائية والطبيعية والهسية لعينت من الزيت المستخدم في قلي رقايق الططلس

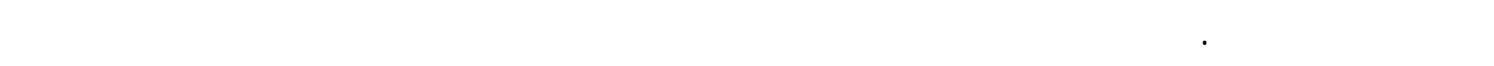

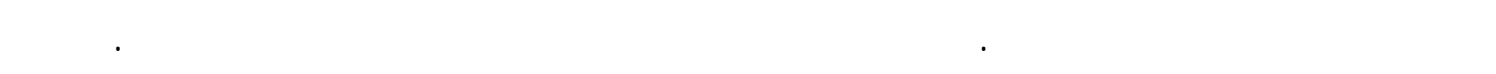

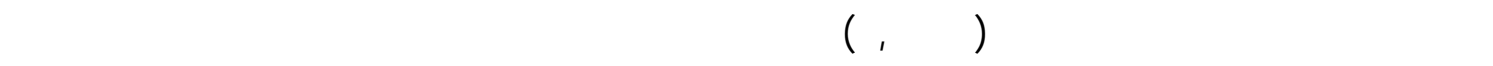

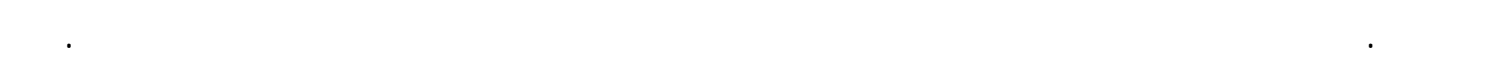

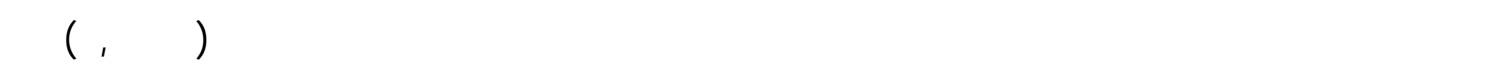

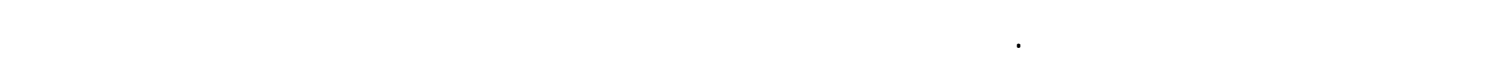
الزيت أثناء عمليك القلي العميق لرقائق الططلس الطمان.

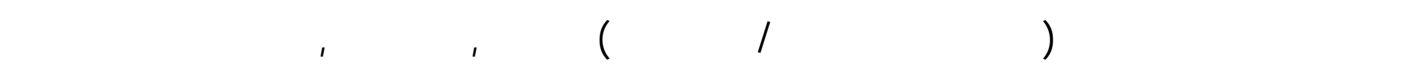

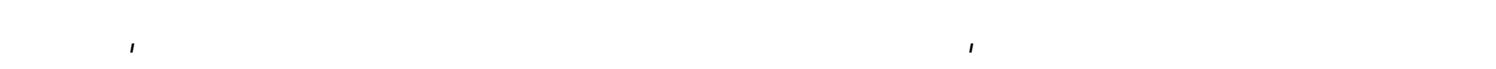

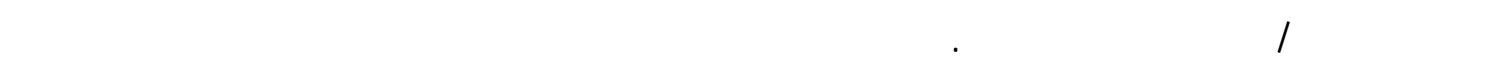

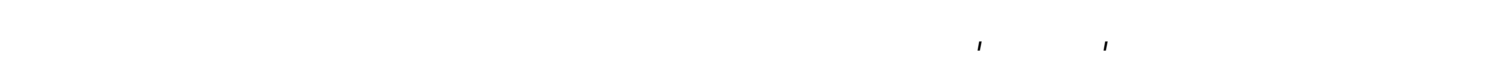

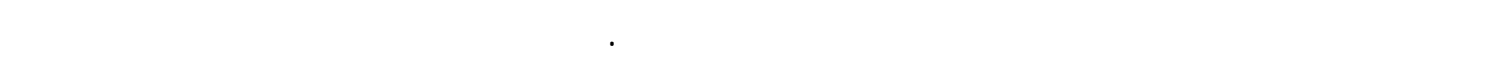

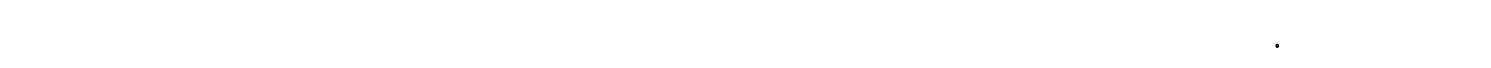

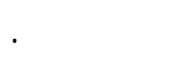

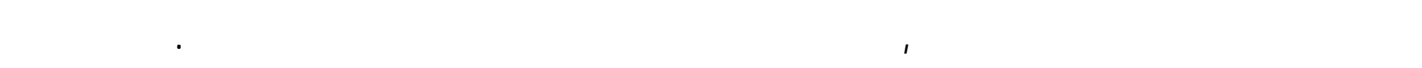

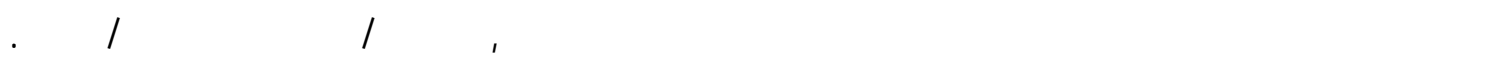

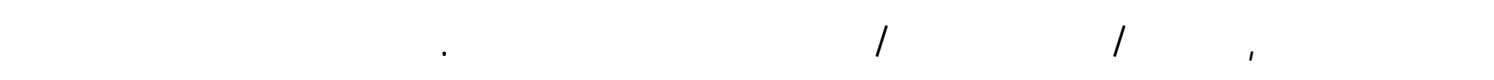

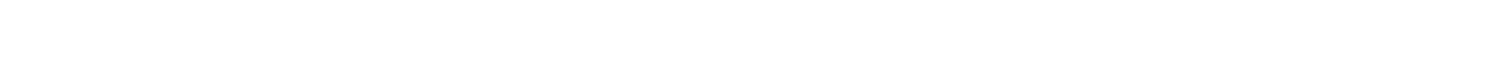

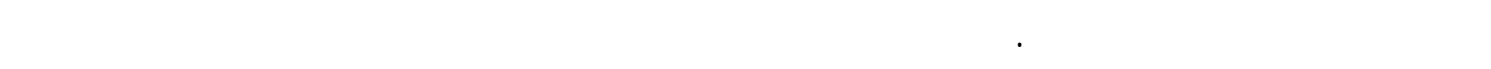
والمتغيرات التابعة للازيت. 